\title{
Babalon, gudinna och ockult kvinnlig rollmodell
}

\author{
Hedenborg White, Manon The Eloquent Blood: The Goddess Babalon and \\ the Construction of Femininities in Western Esotericism (diss.). Teologiska \\ institutionen, Uppsala universitet 2017 (502 sidor)
}

ÄNDA SEDAN KYRKORNAS makt kraftigt inskränkts i stora delar av västvärlden har det vuxit fram ett myller av alternativa, oftast små religiösa rörelser. En av de mest fängslande stiftarna av en sådan minoritetsreligion var Aleister Crowley (I875-1947). Crowley växte upp i England i en fundamentalistisk och puritansk kristen sekt, Plymouthbröderna, och revolterade redan som ung mot dess strikta moralregler. Trots hans avståndstagande från den tidens kristet präglade moral formulerades hans revolt delvis i termer tagna från kristendomen - han identifierade sig med Odjuret i Uppenbarelseboken. I sin frigörelseprocess kom han att göra uppror mot en lång rad normer som kännetecknade det tidiga I9oo-talet: han var bland annat öppet bisexuell och hade förhållanden med en rad såväl kvinnliga som manliga partners i en tid då relationer mellan individer av samma kön kunde leda till åtal och betraktades av allmänheten som moraliskt djupt anstötliga.

År 1904 sade han sig ha mottagit ett budskap från en okroppslig andevarelse, Aiwass, enligt vilket en ny epok i mänsklighetens historia nu inletts. Han skrev ned budskapet i en kortfattad och kryptisk text, Liber AL vel legis, och utvecklade gradvis en religion, thelema, som har denna text som sin centrala skrift. I Crowleys innovativa religionsbild- 
ning ses sexualiteten som en suverän kraft och en i bokstavlig mening magisk metod till personlig förvandling. I de mera avancerade stadierna av Crowleys magiska väg gällde det att bryta mot olika sexuella tabun. Han levde som han lärde och lät sig i en magisk ritual, utförd i den algeriska öknen, penetreras analt av en sina närmaste lärjungar, eftersom detta enligt Crowley skulle bryta ned hans ego och leda till ett genombrott på vägen mot allt djupare insikter.

Det är i denna sociala och kulturella kontext man ska uppfatta gudinnan Babalon som nämns i titeln på Manon Hedenborg Whites avhandling. Gudinnan introduceras kort i Liber AL vel legis, men föreställningarna om henne utvecklas i Crowleys senare skrifter och i texter författade av personer med intresse för hans tankegångar. Namnet på denna gudinna leder tankarna till Uppenbarelseboken, där den babyloniska skökan är en symbol på ondskan, men i karakteristisk crowleysk anda vänds den kristna symboliken upp och ned. En av Babalons viktigaste aspekter är nämligen att representera en fri och subversiv kvinnlig sexualitet.

En rad komplexa och symboliskt laddade visioner av gudinnan som Crowley upplevde 1909 övertygade honom om att hon representerar den förlust av egot som den måste uppleva som gett sig ut på magins väg och vill initieras in i de mest avancerade nivåena av ockult visdom. Crowley såg dessutom Babalon inte bara som en gudinna, utan också som en roll som kvinnor av kött och blod - kort sagt, hans älskarinnor - kunde fylla. Den schweizisk-amerikanska ockultisten Leah Hirsig sökte I919 upp Crowley och fick denna upphöjda status av honom. Under de nästkommande fem åren utvecklade de en lång rad sexualmagiska praktiker tillsammans.

Babalonfiguren återkommer därefter inte bara i Crowleys senare skrifter, utan togs över av andra som intresserade sig för thelema. En av de mest färgstarka av de personer som tas upp i avhandlingen är Jack Parsons, som hade en ledande roll i utvecklingen av USA:s rymdprogram, men som privat var en excentrisk utövare av rituell magi. Parsons liv har skildrats $\mathrm{i}$ ett par biografier, men hans ockultism har varit ett betydligt mindre utforskat ämne. Hedenborg Whites avhandling tillför 
ny kunskap om hans kreativa bruk av Crowleys idéer och inte minst hans Babalonfigur. Hos Parsons får hon drag av en erotisk, feminin och revolutionär messiasfigur. Tillsammans med L. Ron Hubbard, som några år senare skulle skapa en av vår tids mest kontroversiella nya religioner, scientologin, utövade Parsons ritualer som skulle låta Babalon inkarneras i en fysisk kropp.

Crowley formulerade sina tankar om Babalon för mer än ett sekel sedan, vid en tidpunkt då normativa föreställningar förknippade kvinnlighet med passivitet och kyskhet, och den kvinna som bejakade sin sexualitet öppet sågs som en femme fatale. Föreställningar om Babalon har som sagt formulerats otaliga gånger sedan dess, vilket gör denna gudinnegestalt till en lins genom vilken man kan se historiskt betingade kulturella (och inte minst motkulturella) konstruktioner av kön, genus och sexualitet utspela sig. Hedenborg White har utfört ett imponerande arbete genom att studera stora textmängder och intervjua ett antal nutida ockultister för att detaljstudera dessa konstruktioner. Hennes avhandling låter sig inspireras av en rad feministiska teoribildningar för att närma sig frågan hur, i ett samhälle präglat av heteronormativ sexualitet och socialisering i relativt rigida könsroller, en figur som Babalon historiskt fungerat, och än i dag fungerar, som ett identifikationsobjekt för kvinnor i magisk-ockulta miljöer, som i henne finner en symbol för en kvinnlig urkraft och en aktiv och experimenterande sexualitet. Avhandlingen kan därmed läsas som en teoretisk reflektion över hur ett begrepp som kvinnlighet kan konstrueras i en (i relation till det omgivande samhället) särdeles alternativ religiös rörelse.

Samtidigt fungerar den som en guide till en för de flesta läsare okänd miljö, befolkad av människor som bröt mot konventionerna och aktivt valde att leva ett liv tvärt emot alla de sexuella normer och de föreställningar om genus och kön som var förhärskande i västerländska samhällen under förra seklets första decennier. Vi kan avslutningsvis återgå till Leah Hirsig, som för precis hundra år sedan tog kontakt med Crowley. I dagboksanteckningar redogjorde Crowley för de sexuella experiment som de gav sig i kast med. Alla gränser för det borgerligt acceptabla skulle utmanas och brytas, de experimenterade med ritualer där smärta 
och symbolisk förnedring utforskades och Crowley underkastade sig Leah som hennes viljelösa slav. Att sådana sadomasochistiska experiment på tu man hand eller med andra partners uppfattades som en väg mot ett genombrott på en andlig initiationsresa visar att västerlandets religionshistoria rymmer några minst sagt oväntade och fascinerande kapitel.

OLAV HAMMER SYDDANSK UNIVERSITET 